\title{
Management of Supply Chain Process for Meat Products
}

\author{
Muhammad Nusran ${ }^{1} ;$ Roslina Alam $^{1}$; Dien Triana ${ }^{2}$; Idris Parakkasi ${ }^{3}$; Tajuddin Abdullah ${ }^{4}$ \\ ${ }^{1}$ Universitas Muslim Indonesia, Makassar, Indonesia \\ ${ }^{1}$ Universitas Muslim Indonesia, Makassar, Indonesia \\ ${ }^{2}$ Politeknik Negeri Ujung Pandang, Makassar, Indonesia \\ ${ }^{3}$ Universitas Islam Negeri Makassar, Indonesia \\ ${ }^{4}$ Politeknik Kesehatan, Makassar, Indonesia \\ Correspondent email: muhammad.nusran@umi.ac.id
}

\begin{abstract}
The purpose of this study is to map the Halal Critical Point of Beef Products and a number of Processed Beef Products and also to create a Supply Chain Process Process Flow System for Meat products. Data and analysis of data explored in this study are stakeholders in the halal supply chain, namely authority institutions such as slaughterhouses (RPH), producers, logistics providers, operators, consumers, and the government by making questionnaires to identify important criteria and sub-criteria. The survey discussed consumer perceptions of halal supply chains of processed beef and beef products using the scoring method. Data processing results can then be analyzed using the Analytical Hierarchy Process (AHP) model. This study is expected to contribute to the selection of important criteria for halal supply chains for Meat products and their processed products, then contribute to the priority index using AHP (Analytic Hierarchy Process).
\end{abstract}

Keywords: Beef, Halal Critical Point, RPH, Supply Chain and AHP

\section{INTRODUCTION}

Beef derivative products have various forms because almost all parts of livestock can be processed into products that are worth selling. Food products derived from cattle that have been widely distributed in the community are quite diverse, for example processed meat, milk, yogurt, cheese, crackers and so on. In general, the derivative products from processed beef are mostly produced by business actors both from the industrial scale, small and medium enterprises (SMEs), as well as street vendors. Basically, people consume a lot of derivative products from processed beef. This is because cows are animals that have fairly complete nutritional value, so people consume them as food ingredients.

The price of beef products now is relatively expensive. The price increase due to the lack of availability of raw materials which causes increasing prices of food products from cattle, especially meat, to reach \pm IDR $100,000 / \mathrm{kg}$. This is also due to the large number of business actors engaged in the beef processing sector (Ministry of Industry, 2013).

This scarcity has caused limited supply in the market which has resulted in an increase in the price of beef products. This scarce supply and high selling price has resulted in the emergence of fraud so that problems arise guaranteeing the quality of halal and beef derivative products. Until now, most consumers still do not know the halal certainty and quality of the products they consume. Therefore, the concept of halal critical point mapping is needed in the process of producing beef derivative products. The problems that occur in the production of beef agroindustry products are:

1. Lack of halal assurance on the beef derivative products that have been widely distributed in community;

2. The flow of the supply chain process for processing beef products that is still not fulfill halal assurance

3. The absence of a halal critical point mapping that is integrated in the process of making beef-based products on the small and medium scale business.

The concept of halal is not limited to food itself, but also to cosmetics, pharmacy, financial services and banking, etc., even tourism (hotels, tours, etc.). According to Islamic law, to determine halal and prohibition does not have to be based on assumptions or feelings of likes and dislikes. If it is so, it is considered as tahakkum (making law in the name of Allah), which is strictly prohibited in Islam. Halal decisions on certain products carried out by people who do not have authority will only make the law incorrect. Consumption of halal products requires certain raw materials, additives, processes, handling and transportation to meet the criteria for halal terms as mentioned above. In addition, the industry must have a good system in order to ensure that the product meets these requirements and no errors are made during the production processes. The system called Halal Assurance System (SJH) is proposed by Apriyantono (2001). This system consists of several components namely:

1. Halal management standards and halal systems. Halal management is managing all 
functions and activities needed to determine and achieve halal products. Halal systems are defined as organizational structures, responsibilities, procedures, activities, capabilities, and resources that together aim to ensure that the product, process or service will be satisfactorily stated or implied as its purpose, namely producing halal products. Basically, a halal system audit standard is conducted to determine the suitability of halal system elements with the specified requirements. The effectiveness of the halal system is applied to meet certain objectives and to verify that the non-conformities identified in the previous audit have been corrected according to the agreement.

2. Haram Analysis Critical Control Point (HRACCP). A system that can show critical points where unclean or najees ingredients can contaminate halal materials, as well as preventive ingredients that will be used for halal food production.

3. Halal database. This consists of a list of materials used for food production, information from the source and preparation of each of the materials mentioned in the list and halal status and other important information. To ensure that the industry has fulfilled the halal requirements in producing halal food, especially those who want to place a halal logo in its packaging, the industry must request assistance from dependence and acceptable halal certification organizations. Halal certification organizations will audit and certify their products, raw materials, additives, production facilities, administration and management. After the industry has received a halal certificate for its products, it can be used as a formal basis for implementing the halal logo. This certificate can also be used to state that the product is halal and hence products can be imported into muslim countries or sold to muslim consumers.

The definition of food according to Law Number 7 of 1996 is everything derived from biological and water sources, both processed and unprocessed, which are intended as food or drinks for human consumption, including food additives, food raw materials, and other materials used in the process of preparing, processing and or making food or drinks (Gemasih, et al 2014). Whereas halal means everything that is permitted, which is detached from the prohibition, and permitted by Allah SWT, while haram is something that is forbidden by Allah SWT with a definite prohibition, where the person who violates it will be punished in the here after and sometimes punished also in the world (Qardhawi, 2002 in Saputra, 2006).

The assurance system, halal is the highest concept of any other quality assurance, which includes Hazard
Analytic Critical Control Points (HACCP), SOPs, GMP / GAP / GFP / GDP / GTP / GCP, and General Decisions and Quality Policies in General (Purnomo, 2013).

Halal can be said as the most important part of every quality assurance. This is because halal is inherent in any other quality assurance. As the highest quality assurance, halal is one of the good requirements in making food products. Therefore, halal products are certainly having high quality standard. Illustration of the importance of halal so it becomes the highest part of any others quality assurance concept can be seen in Figure 1 as follows.

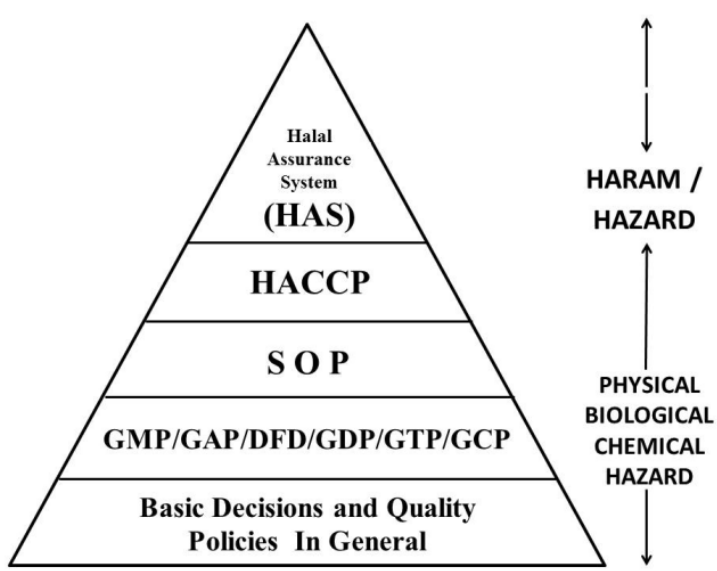

Figure 1. Halal as the highest Quality Assurance (Source: Dahlan in Purnomo, 2013)

In the Government Regulation of the Republic of Indonesia Number 69 of 1999 on the Article 1, halal food defines as food that does not contain elements or ingredients that are haram or prohibited for consumption by muslims, both concerning food raw materials, food additives and other supporting materials including ingredients from food processed through genetic engineering and food irradiation, and whose management is carried out in accordance with the provisions of Islamic religious law. With these regulations issued, halal assurance is the most important requirement in creating food products in Indonesia, where the majority of the population is muslim

\section{Halal Assurance for Slaughterhouse}

Animals must be treated properly to avoid pressure before being slaughtered. Stunning should not kill animals before they are slaughtered, do not harm animals, do not cause permanent damage to the body/organs and are examined by supervisors. The Stunning method must be regularly validated and verified by LPPOM MUI. Mechanical cutting carried out in a factory or abattoir must follow a number of Islamic rules such as stating "Bismillahi Allahu Akbar or Bismillahir Rahmaanir Rahiim" when pressing the machine button. 
The slaughterhouse system must have written procedures to ensure traceability of halal-certified meat. This system must obtain evidence that the meat is produced from halal animals, cut into the right halal method in cutting facilities that are in accordance with halal requirements.

There are some procedures for handling products made from materials and facilities that do not meet the criteria of LPPOM MUI, such as (a). Non-conformity products may not be sold to muslim consumers, (b). If a non-conformity product has been distributed, it must be withdrawn.

Internally, slaughterhouses must have written procedures for internal audits scheduled at least twice a year. Internal audit must be carried out by independent and competent personnel. The results of internal audits must be reported to all relevant departments responsible for monitoring activities. Corrective action must be carried out within the time limit and must be able to resolve internal audit findings. A summary of the results of the internal audit must be sent to LPPOM MUI and the implementation of internal audits must be documented.

\section{Halal Critical Point}

Halal critical point is an area/place/position which is considered prone to be halal. Determination of halal critical points in the product manufacturing process is carried out by conducting a search of each process activity. This search is useful for identifying critical points that cause unbalance of the produced products. In the production process of making halal products, halal critical points can be defined and mapped by looking at the Standard Operating Procedure (SOP) of each activity that occurs in it. According to LPPOMMUI (2008), the SOP for halal production is done by looking at:

1. Making worksheets must refer to formulas and material matrices known by LPPOMMUI.

2. Materials that can be used in halal production are only contained in the list of materials that LPPOM-MUI has already known and have obtained halal passes.

3. Material is ensured to be free from unclean contamination and unclean ingredients.

4. The production line is confirmed to only be used for halal materials.

5. If the production line is also used for materials that have not been certified halal, then the cleaning procedure is sure to eliminate/avoid products from cross contamination.

6. If there are products that are not certified to contain pork derivatives, the equipment and production line are certainly completely separated.

7. It must be ensured that the production area must not have materials or goods that are not used for production.
8. Production records are well and completely documented.

The critical point of halal in the product manufacturing process, in general, can follow from the prohibited tipping point of the Haram Analysis Critical Control (HrACCP) product, but a halal-haram product can follow the principle followed by Hazard Analysis Critical Control Points (HACCP) but in this case aimed at efforts to prevent the entry of unclean ingredients into the production system as early as possible (Estuti, 2005). According to Apriyantono et al. (2003) in Estuti (2005) the application of Haram Analysis Critical Control Points (HRACCP) consists of six components, namely:

1. Identify all ingredients which are unclean and najis. 2. Identify critical control points. 3. Establish monitoring procedures. 4. Make corrective actions. 5. Make a document-recording system. 6. Make verification procedures.

In controlling the halal critical point, control is carried out on each process flow until the end of the product manufacture. Determination of halal critical point control begins at each stage of the process up to the consumers who consider the halal products and how to prevent the entry of illicit materials in the production process to the final product (Apriyantono et al., 2003 in Estuti (2005).

\section{Halal Supply Chain on Beef}

Basically the supply chain process of beef products and derivatives is divided into two sectors, namely the upstream sector and the downstream sector. The upstream sector is a sector that acts as the procurement of cattle to reach slaughtering houses (RPH), while for the downstream sector is a sector that acts as the procurement of beef to reach the procurement of processed/derivative products. Supply chain flow of beef-based products with the relevance of entities that play a role in them. The linkages of entities/actors that play a role in the supply chain process of beef products and their derivatives consist of several different and interconnected actors in each of their sectors.

\section{Supply Chain Process Flow in Slaughtering house}

Slaughterhouse (RPH) is a unit of facilities and facilities dedicated by the government as a location for specially designed slaughterhouses in accordance with SNI 01-6159-1999. Judging from the substance of ownership, RPH is grouped into two: governmentowned slaughterhouse (UPTD RPH) and nongovernment owned slaughterhouse (private).

Actors who play a role in the two types of RPH are relatively similar, consisting of RPH employees, slaughterers, and actors from the downstream and upstream sectors. Judging from the process, RPH employees are actors who act as control holders of all activities that occur in the RPH, including management, supervision and maintenance. In 
accordance with the ownership status of RPH, the employees are divided into two, namely official staff (UPTD Government RPH) and non-official employees (Private RPH).

Each employee has a specific task from each process starting from the arrival of the cow, the cutting process to the process of sending beef. Butchers are entities that act as slaughterers. In the process of slaughter, the slaughterer must have special criteria that are in accordance with the Islamic Shari'a, ie the perpetrator must be Muslim, balig and understand how the slaughter process is good without any elements of torture. Each RPH is required to have a slaughterer who has been recognized by the MUI with proof of certificate as a professional slaughterer and in accordance with special criteria. This is because it will provide Assurances to RPH to produce halal meat products.

\section{Halal Critical Control Point in Slaughtering house}

The halal critical control point is a control position where the lighting will be prohibited to appear. Basically, the halal critical control points of beef-based products originate from slaughterhouse, the halal of a beef product can change if further handling and processing occurs. Animal Slaughtering house (RPH) are a starting point for halal critical control points from beef-based products. In this position, RPH is dedicated as an initial location with the potential for the emergence of halal critical points. Slaughtering and handling carried out by RPH are the main factors that must meet the quality, health and halal quality standards. The halal critical control point in the dominant RPH lies in, first, the religion of the slaughterer (Islam), the knowledge of the slaughterer, the behavior of the slaughterer (baligh/adult), and the cleanness of the slaughterer.

Secondly, the type of commodity of animals slaughtered in RPH; thirdly, the differentiation of slaughter facilities and infrastructure if RPH has a type of non-halal slaughterhouse commodity (pig); fourth, the method of slaughter in accordance with the Islamic Shari'a and subsequent handling. Basically, slaughterers in slaughterhouses are required to be Muslim. Besides, the slaughterer must also have knowledge of how to slaughter according to Islamic Shari'a, have good behavior (adult), and pay attention to cleanness in each process.

Types of animals can be categorized as critical control points if there are shelters and slaughterhouses in addition to halal animals. With an explanation of the types of animals, it is very clear that the differentiation of facilities and infrastructure must be different between halal and non-halal animals. This difference is one of the halal critical control points that must be considered in the cutting process. The most visible halal critical control point is the slaughter method that must be carried out in accordance with the Islamic Shari'a, namely by reciting prayers (BismillahiAllahu
Akbar) and deciding three channels, namely the respiratory tract, food and blood with one cut.

\section{Mapping of Halal Critical Points}

Slaughterhouse (RPH) is a place to slaughter livestock dedicated by the government as a facility to support food security in an area with the building that meet certain requirements and techniques.

From the results of the halal critical point mapping, it can be stated that the RPH is an initial critical control point for the product that will be produced if the product uses animal meat. The halal critical control points of slaughterhouses are seen from the types of animals and the process of slaughter of animals carried out in accordance with Islamic Shari'a as well as safe and good handling (avoiding dirt and najees). Types and sources of data to map halal critical points in the process flow supply chain this beef-based agroindustry product uses primary data and secondary data.

1. Primary data is obtained through direct observation with interview techniques for actors related to mapping starting from Slaughtering house (RPH), meat markets, beef-based product processing industries (meatballs), and expert respondents who have science in this mapping.

2. Secondary data obtained from various sources, namely articles sourced from the internet media, textbooks, and data from the government related to the problems taken. The types and sources of primary data needed in this mapping and after that are described.

Secondary data is data needed in the initiation of understanding and studying networks that are related to the halal product chain process flow, while the primary data is the data needed as an understanding of the supply chain process framework for beef-based products.

With this data, it is expected to provide a halal critical point mapping in the supply chain process of beefbased products.

\section{Urgency of Halal Critical Points}

The supply chain of animal origin agroindustry products is divided into two sectors, namely the upstream sector and the downstream sector, the upstream sector starts from livestock entrepreneurs (cattle) to reach Slaughterhouse, while the downstream sector starts from RPH, markets/meat kiosks, to reach derivative processing. Mapping of halal critical points in the supply chain process of beef-based agroindustry products can be identified from each variable of machine, man, material, method, and money resources with factor weights and assessment of predetermined criteria for fulfilling the halal critical point. The state of halal critical point mapping in the supply chain process flow has factors that determine the halal according to 
the weights that have been obtained using the Analytical Hierarchy Prosess (AHP) method.

Machine (facilities and equipment) is a resource that has the lowest average score of "good enough" in the mapping of halal critical points in the supply chain process of beef-based agroindustry products. The need for supervision management that is integrated with the right timeframe in the flow of the supply chain processes by looking at the halal critical point factor towards the resources used. The need to change the behavior of the entity can be taken by having extensive knowledge of halal products and a strong awareness in creating assurance and quality halal products. Government policies and strategies that have a developmental impact on the halal of beef-based agroindustry products, in order to improve halal products circulating in the community are necessary. Further mapping by adding locations to better reflect the state of halal critical point mapping in the supply chain of cattle-based agroindustry products as a whole is also necessary.

Criteria for Slaughterhouse (RPH) Registration are; producers must register all slaughterhouses that are in the same company, they must employ slaughterers who are Muslim and trained in the slaughter process in accordance with Islamic law (have slaughter certificates), the slaughter locations are far from farms and slaughter of pigs, they apply the standard of slaughter according to Islamic law.

\section{METHOD AND MATERIAL}

There were some stages that had been carried out in this study, namely: stage of literature study, stage of field studies and data collection, stage of data collection and information on halal critical points, stage of data processing, mapping analysis of AHP analysis, and stage of drawing conclusions and recommendations.

In this study, a number of in-depth interview methods and data collection methods with questionnaires in the process of beef products are used. The questionnaire aims to facilitate the resource person in answering the questions asked. The format and contents of the questionnaire were adapted and developed based on the needs of data and information related to the questionnaire

Respondent data relating to the Halal Certification System are as follows:

1. Number of beef products that are Halal certified,

2. Demand for beef products in Makassar,

3. Amount of slaughterhouses in Makassar

4. Government policies and support

\section{Identificationand Data Collection}

The types and sources of data in this study were obtained from:

1. Primary Data is data obtained by conducting direct observations with interviews with leaders and employees, producers, consumers and many related elements (such as in the profession of respondents)

2. Secondary data is data obtained from several literatures, especially those related to the problems encountered in research as a theoretical foundation as well as supporting in writing.

In this study, the primary data is questionnaire data with data sources from a number of producers of beef products and slaughterhouses (RPH), namely:

1. Large-scale producer/ company

2. Medium-scale producers /companies

3. Small-scale producers /companies

\section{Stages of Data Collection and Information on Halal} Critical Points

Types and Sources of Data include Initiation of understanding and studying related networks in the process flow of halal production supply chain such as:

1. Data on the distribution of RPH locations

2. Data on local and imported beef production

3. Data on halal certified meatball products

4. Entities/stakeholders who play a role in the process of producing beef and derivative products

5. Data on RPH Facility Feasibility Checklist

6. The process of processing derivative products carried out by the meatball, shredded meat, sausage, and chips, processing industry also with well-known local culinary such as coto, konro, pallubasa and so on

7. Document flow related to supervision and quality assurance and halal in the production process

8. AHP weighting

9. Assessment data

\section{Stages of the Data Processing}

The data processing stage and the fixing of halal critical points consist of several processes. Data collection was done by survey method using interview and observations techniques directly at each entity and stakeholders in each process. At the time and after data collection, the determination of variables, factors and fulfillment criteria for halal critical points in the supply chain process flow can be carried out. Determination of variables, factors and compliance criteria for the halal critical point aims to find out which parts are the locations of the halal critical point of each supply chain process flow. After obtaining the variables, factors and criteria for fulfilling the halal critical point, the data processing can be carried out with the weighting method that has been determined and discussed by expert respondents who have knowledge related to this mapping using the Analytical Hierarchy Process (AHP) method.

AHP method has a function as a determinant of uncertainty perspective in comparing pairs on each 
factor according to the number of indicators that have been determined and to determine which factors are the most influential and important in the mapping of halal critical points.

Weighting aims to determine the priority value of each halal critical point factor of each variable that has been determined from the results of determining the halal critical point.

In addition to determining weighting using the AHP method, respondents from experts and the research team are required to provide an assessment of each compliance criteria for the halal critical points that have been determined for each sample area to provide a mathematical description of the actual situation, which area includes the location of the Government Animal Slaughtering house (RPH), meat market location and industrial location for SMB scale packaging meatballs.

\section{RESULTS AND DISCUSSION \\ Data Input}

The input data to be entered will provide scores and weights as a result of the calculation of a number of formulations specified. The AHP weighting method and score setting design can be seen in the formula as follows:

Determination of the importance of the halal critical point factor weight score.

$(\mathrm{Bn})=$ NPriority $\mathrm{AHP} f n \times 100 \%$

Where:

$\mathrm{Bn}=$ Importance of the halal critical point factor $(\%)$

NPriority $\mathrm{AHP}_{-} f n=$ Score AHP (Expert) Priority Factors Of Each Variable

Determination of the conversion score of each factor: $\mathrm{nKon} \_\mathrm{fn}=\Sigma \mathrm{nKP} n \mathrm{p} \_\mathrm{fn}$

$$
\text { TotalK } \mathrm{K} \times 5 \text {. }
$$

Where:

nKon_fn $=$ conversion score

$\mathrm{nKPn} \_\mathrm{fn}=$ Score of fulfillment criteria for each factor $\mathrm{Kp}=$ Fulfillment criteria

Determination of factor score values of each respondent:

$s f \_f n=$ nKon_fn_rata $\mathrm{x}$

Bn...........

$s f \_f n=$ Scores of each resource variable factor

The preparation of the assessment criteria for the fulfillment of the halal critical points will be based on the number of respondents involved.

Table 1: Scoring Factor Criteria

\begin{tabular}{|c|c|c|c|}
\hline \multicolumn{4}{|c|}{ Scoring Factor Criteria } \\
\hline \multicolumn{3}{|c|}{ Sample Area 1,2...n } & Average \\
\hline R1 & R2 & R3 & \\
\hline $\mathrm{nKP} 1 \_f n$ & & & \\
\hline $\mathrm{nKP} 2 \_\mathrm{fn}$ & & & \\
\hline & & & \\
\hline $\mathrm{nKPn}$ fn & & & \\
\hline
\end{tabular}

\begin{tabular}{|c|c|c|c|}
\hline \multicolumn{4}{|c|}{ Scoring Factor Criteria } \\
\hline \multicolumn{3}{|c|}{ SampleArea 1,2...n } & Average \\
\hline R1 & R2 & R3 & \\
\hline nKXPn_fn & & & \\
\hline nKPn_fn & & & nKon_fn_rata \\
\hline
\end{tabular}

Note:

$\mathrm{R}=$ Respondent

nKon_fn_rata = Average conversion value from the respondent's assessment

Assessment is obtained by providing a range of scores 0 to 1 to give meaning to how fulfilled the fulfillment criteria for the established halal critical points. To see the rating scale of the predetermined criteria for compliance with the halal critical points, it can be seen in the following table.

Table 2: Rating Scale of Fulfillment Criteria

\begin{tabular}{|c|c|c|c|}
\hline & $\begin{array}{l}\text { The closer } \\
\text { of } \\
\text { Value } 1 \text { is, } \\
\text { the higher } \\
\text { of the } \\
\text { fulfillment }\end{array}$ & Score & $\begin{array}{c}\text { Criteria of } \\
\text { Fulfillment } \\
\text { Factors Score }\end{array}$ \\
\hline \multirow{11}{*}{$\begin{array}{l}\text { Assessment } \\
\text { of } \\
\text { Fulfillment } \\
\text { Criteria }\end{array}$} & \multirow{11}{*}{$\sqrt{b}$} & 0 & Not fulfilled \\
\hline & & 0,1 & \multirow{9}{*}{$\begin{array}{l}\text { The Score of the } \\
\text { Fulfilled } \\
\text { Fulfillment } \\
\text { Criteria } \\
\text { Based on the } \\
\text { determined } \\
\text { factors }\end{array}$} \\
\hline & & 0,2 & \\
\hline & & 0,3 & \\
\hline & & 0,4 & \\
\hline & & 0,5 & \\
\hline & & 0,6 & \\
\hline & & 0,7 & \\
\hline & & 0,8 & \\
\hline & & 0,9 & \\
\hline & & 1 & Fulfilled \\
\hline \multicolumn{4}{|c|}{$\begin{array}{l}\text { Conversion assessment was obtained after an } \\
\text { assessment of the criteria for fulfilling the halal critica } \\
\text { point factor had been carried out. To find out the scale } \\
\text { of conversion rating of the criteria for meeting the hala } \\
\text { critical points can be seen in Table } 3 \text {. } \\
\text { Table } 3 \text { : Conversion Scoring Scale }\end{array}$} \\
\hline \multirow{6}{*}{$\begin{array}{c}\text { Conversior } \\
\text { Scoring }\end{array}$} & \multicolumn{2}{|c|}{ Score } & $\begin{array}{c}\text { Conversion Score } \\
\text { Criteria }\end{array}$ \\
\hline & \multicolumn{2}{|c|}{1} & Very Not Ideal \\
\hline & \multicolumn{2}{|c|}{2} & Not ideal \\
\hline & \multicolumn{2}{|c|}{3} & Quite ideal \\
\hline & \multicolumn{2}{|c|}{4} & Ideal \\
\hline & \multicolumn{2}{|c|}{5} & Very ideal \\
\hline
\end{tabular}

In the assessment of conversion obtained, the score can be interpreted by the color level specified in the Table of Conversion Scoring Meaning by Chroma.

Table 4: Conversion Scoring Meaning by Chroma

\begin{tabular}{|l|l|l|l|l|l|l|l|l|l|l|}
\hline 0 & 0,5 & 1 & 1,5 & 2 & 2,5 & 3 & 3,5 & 4 & 4,5 & 5 \\
\hline & & & & & & & & & & \\
\hline
\end{tabular}

*The closer to the dark red color, the more ideal the assessment of the sample area. 
Decisions in the assessment that have been obtained can be adjusted according to the assessment decision range in Table 5.

Table 5: Range of Conversion Assessment Decisions

\begin{tabular}{|c|l|l|}
\hline \multicolumn{1}{|c|}{ Range } & \multicolumn{2}{|c|}{ Decision } \\
\hline $1<\mathrm{n}<2$ & $\begin{array}{l}\text { Between very ideal } \\
\text { and not ideal }\end{array}$ & $\begin{array}{l}/ /<0.50 \text { tend to be very } \\
\text { not ideal and } \\
0.50 \text { tend to be not ideal }\end{array}$ \\
\hline $2<\mathrm{n}<3$ & $\begin{array}{l}\text { Between not ideal } \\
\text { and quite ideal }\end{array}$ & $\begin{array}{l}/ /<0.50 \text { tend to be not } \\
\text { ideal and }>0.50 \\
\text { Tend to be quite ideal }\end{array}$ \\
\hline $3<\mathrm{n}<4$ & Between quite & $\begin{array}{l}/ /<0.50 \text { tend to be quite } \\
\text { ideal and }>0.50 \\
\text { Tend to be ideal }\end{array}$ \\
\hline $4<\mathrm{n}<5$ & Between ideal and & $\begin{array}{l}/ /<0.50 \text { tend to be ideal } \\
\text { and }>0.50 \text { tend to be } \\
\text { very ideal }\end{array}$ \\
\hline
\end{tabular}

After obtaining the factor weight of each variable, the determination of the score of each factor is obtained from the multiplication of the average conversion score of the compliance criteria for the halal critical point with the weight score of each factor. AHP weighting given to each factor is done to find out which factors have the greatest score and the smallest score that can determine the priority of interest from each predetermined halal critical point factor of each variable. After getting the score on each variable factor, it can be summarized from the factor score value to determine the amount of the total score obtained, as an attempt to find out which variable has the highest or lowest score of reviewing the predetermined halal critical point factor. This total score is useful to find out the state of the variables in each sample area. The weighted design that has been formulated is presented in Table 6.

Table 6: Weighting Design

\begin{tabular}{|c|c|c|c|c|c|c|}
\hline No & $\begin{array}{c}\text { Variabl } \\
\mathrm{e}\end{array}$ & $\begin{array}{c}\text { Facto } \\
\mathrm{r}\end{array}$ & $\begin{array}{c}\text { Priorit } \\
\text { y } \\
\text { Score } \\
\text { by } \\
\text { AHP } \\
\text { Metho } \\
\text { d }\end{array}$ & $\begin{array}{c}\text { Value } \\
\text { of } \\
\text { Weight } \\
\text { Interest } \\
\text { s } \\
\text { Factor } \\
\text { by } \\
\text { AHP } \\
\text { method } \\
\%\end{array}$ & $\begin{array}{c}\text { Criteri } \\
\text { a of } \\
\text { scorin } \\
\mathrm{g} \\
\text { factor }\end{array}$ & $\begin{array}{c}\text { Scor } \\
\text { e }\end{array}$ \\
\hline 1 & & & & & & \\
\hline 2 & & & & & & \\
\hline & & & & & & \\
\hline $\mathrm{n}$ & & & & & & \\
\hline total & & & & & & \\
\hline 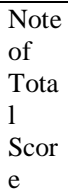 & & & & & & \\
\hline
\end{tabular}

Notes:

1. nKon_fn_rata $=$ The average conversion score from the respondent's assessment

2. NpriorityAHP_fn = Score of AHP Factor Priority (Expert).

3. $\Sigma$ nKon_fn_rata $n i=$ Amount of conversion average score of respondent's assessment criteria. $=1$ 4. $\Sigma s f_{-} f=1=$ Total score for each variable factor. ni

Notes:

$\sum s f_{-} f i$

$n i=1$ :

- Obtained Depending on the Scale of Assessment of Specified Factors.

- Classification of Groups Results of Total

Assessment Depends on Total Divided on Number of Variables

After carrying out the weighting design, a plot of results can be done with variables, factors, weighting factors and scores that have been obtained.

Notes:

$\sum s f_{-} f i$

$n i=1$ :

- Obtained Dependence on the Scale of Assessment of Specified Factors.

- Classification of Groups Results of Total Assessment Depends on Total Divided on Number of Variables

After doing the weighting design, designing a plot of results with variables, factors, weighting factors and scores that have been obtained can be done. The description is presented in Table 7 .

Table 7: Description of Total Scores

\begin{tabular}{|c|c|c|}
\hline Range & Notes & Symbol \\
\hline $401 \mathrm{~s} / \mathrm{d} 500$ & Very good & A \\
\hline $301 \mathrm{~s} / \mathrm{d} 400$ & good & B \\
\hline $201 \mathrm{~s} / \mathrm{d} \mathrm{300}$ & Good enough & $\mathrm{C}$ \\
\hline $101 \mathrm{~s} / \mathrm{d} \mathrm{200}$ & Less good & D \\
\hline $0 \mathrm{~s} / \mathrm{d} 100$ & Very bad & E \\
\hline
\end{tabular}

*obtained depends on the conversion rating scale

Considering the halal critical point factor in the supply chain process of beef-based agroindustry products is done by looking at 5 (five) influencing resources including machinery, people, materials, methods and money. These five resources are very influential to reflect how the state of the halal critical points of the products to be produced in each sample area.

\section{Conclusions}

By doing this research, some advantages can be drawn from the existence of halal certification on beef products, namely:

1. With a system of mapping, halal beef products and a number of processed beef offered, they will help in making halal certification policies.

2. Increased consumer trust in the available halal beef products.

3. There is a sense of security and consumer support in consuming halal beef products and a number of processed beef.

\section{References}

Apriyantono A, Hermanianto, dan Nurwahid. (2003) Pedoman Produksi Halal. Departemen Teknologi pangan IPB Bogor 
Apriyantono, A. (2005). Masalah Halal Kaitan antara Syar'i, Teknologi dan Sertifikasi. Penerbit PT Kiblat Buku Utama. Bandung.

Badan Pusat Statistik Provinsi. (2012). Dalam Angka, inFigurers.

Daging Sapi Bermutu dan Halal di Indonesia. Jurnal Surya Agritama, 2(1)

Dahlan, W. 2009. Global Halal Food Market and Future Halal Science

Hosen, M.N. (2008). Panduan Umum Sistem Jaminan Halal LPPOM-MUI. Lembaga Integrasi Pengolahan dan Diseminasi Statistik.

Jamaran, Irawadi. (2011). Sosialisasi Halal Harus Ditingkatkan.

http://www.halalmui.org/index.php?option=com _content\&view=article\&id Accessed on $13^{\text {th }}$ April, 2013 (in Indonesia)

LPPOM MUI. (2013). Profile LPPOMUI Pusat, Lembaga Pengkajian Pangan, Obat-obatan dan Kosmetik, Majelis Ulama Indonesia.

Majelis Ulama Indonesia. (2010). Himpunan Fatwa Majelis Ulama Indonesia. Jakarta: Sekretariat Majelis Ulama Indonesia

Nusran, Muhammad, Irawadi Jamaran, Taufik Nur, (2013). Analysis of Policy and Design for Acceleration of Halal Certification Program, Seminar Nasional Teknologi Industri (SNTI I 2013) Makassar Indonesia ISBN No: 978-60214537-0-4
Nusran, Muhammad., et al., (2013). Analysis Of System Dynamics On The Role Of LPPOM MUI And Government In Implementation Of Halal Certification In Indonesia, Proceedings of International Conference on Halal Issues and Policies, Halal Centre UMI. ISBN: 978-60218603-3-5

Purnomo, D. (2013). Konsep Ketelusuran Jaminan Mutu Dalam Infrastruktur Logistik dan Pustaka Binaman Pressindo, Jakarta.

Qardhawi, Y. (2002). Halal dan Haram. Terjemahan A.S. Al-Falahi. Robbani Press, Jakarta.

Saaty, T. L. (1993). Pengambilan Keputusan Bagi Para Pemimpin: Proses Hirarki Analitik

Saaty, T. L. (2011). The Analytic Hierarchy Process. Planning, Proirity Setting, Resource

Sampurno, (2001). Label Pangan dan Label Peran: Dalam Prespektif Peran, Tugas dan TanggungJawab BPOM. Badan POM, Jakarta

Situbondo. (2012). Available at http:// epetani.deptan.go.id/blog/jenis-jenis-sapipotong-diindonesia-4037. Diaksestanggal 30 Oktober 2017.

Soeparno. (1994). Ilmu dan Teknologi Daging. Gadjah Mada University Press. Yogyakarta.

Yaqub, Ali Mustafa. (2009). Kriteria Halal Haram. Jakarta: Pustaka Firdaus

Zawanah, H Munir, dan A Muhaimin. (2008). Halal: Antara tuntutan Agama dan Strategi 